CORRIGENDUM

\title{
Mesoscale distribution and functional diversity of picoeukaryotes in the first-year sea ice of the Canadian Arctic
}

Kasia Piwosz, Józef Maria Wiktor, Andrea Niemi, Agnieszka Tatarek and Christine Michel

The ISME Journal (2014) 8, 1152; doi:10.1038/ismej.2014.2

Correction to: The ISME Journal (2013) 7, 1461-1471; doi:10.1038/ismej.2013.39; published online 21 March 2013

Since the publication of this article, the authors have identified an error on page six of their article, namely that the given number of of pavlovophytes was incorrectly listed as ' $3.1 \times 10^{7}$ cells $\mathrm{m}^{-3}$, , whereas it should have been listed as ' $3.3 \times 10^{8}$ cells $\mathrm{m}^{-3}$ '.
The correct sentence is as follows:

Pavlovophyceae were relatively numerous at station one $\left(6.8 \times 10^{6}\right.$ cells $\mathrm{m}^{-2}, 3.3 \times 10^{8}$ cells $\left.\mathrm{m}^{-3}\right)$, where they contributed ca. $4 \%$ of total picoeukaryote numbers, and $63 \%$ of haptophyte numbers.

We apologise for any inconvenience this may have caused. 